AGRICULTURE AND BIOLOGY JOURNAL OF NORTH AMERICA

ISSN Print: 2151-7517, ISSN Online: 2151-7525, doi:10.5251/abjna.2011.2.1.173.181

(C) 2011, ScienceHuß, http://www.scihub.org/ABJNA

\title{
Soil fertility management practices of cocoa farmers in the Eastern Region of Ghana
}

\author{
Francis Baah ${ }^{*}$, Vincent Anchirinah, Frederick Amon-Armah \\ Cocoa Research Institute of Ghana, P.O. Box 8, Tafo-Akim, Ghana \\ [ ${ }^{\star}$ Corresponding author: email - achamfour1966@gmail.com]
}

ABSTRACT

\begin{abstract}
National outputs of cocoa beans in Ghana has seen appreciable increases in the last six years due in part to pragmatic policies including the national control of pests and diseases on all cocoa farms, the increased use of fertilizers on farmers' farms and increase in the producer price paid to farmers. However, productivity on farmers' farms remains low at $400 \mathrm{~kg} / \mathrm{ha}$ against potential yield of over 2.5 tonnes per hectare. The continuous mining of inherent fertility of cocoa soils without replenishment has been identified as major cause of the low productivity of cocoa farms. Using structured survey instruments, this study sought to identify farmer soil fertility management practices that enhances yield and which could be improved by way of research outcomes. A total of 150 farmers from three districts in the Eastern region were randomly selected and interviewed on one-on-one basis between July and October 2008. Farmers' soil fertility management practices included chemical and organic fertilizer application, control of erosion and mulching. Farmers who are members of farmers' associations had better access to fertilizers and also applied the fertilizers correctly and at the right time. The effectiveness of fertilizer application was dependent on effective control of blackpod disease, capsids and judicious pruning and shade management. The findings imply that intensive education of farmers on the need to carry out recommended husbandry practices was critical if soil fertility management strategies are to be translated into improved on-farm productivity.
\end{abstract}

Keywords: Cocoa, Soil Fertility, Fertilizer, Productivity, Black pod disease, Capsids, pruning, Shade Management.

\section{INTRODUCTION}

Agriculture remains the largest sector in the Ghanaian economy in terms of its contribution with the cocoa sector being the most critical and contributing 31.8 percent to foreign exchange earnings and 28 percent of agricultural growth in 2006 (Institute of Statistical, Social and Economic Research, 2008). In recent years, cocoa production has picked up due in part to higher producer prices, liberalization of internal marketing, establishment of a price stabilisation system, government-backed rehabilitation programmes, control of pests and diseases programme, fertilizer credits and the privatization of input supply to farmers (International Cocoa Organisation, 2007).

Despite the recent gains, concerns over persistently low productivity on farmers' farms remain. Average yield on farmers' farms is $400 \mathrm{~kg}$ per hectare against yields of 2.5 tonnes per hectare obtained on research and 'high tech' farms (these are farmers' farms where all research recommendations are applied). The recent upturn in national output is attributed to increases in area under cocoa rather than productivity increases (Figure 1). Given the fact that the Western region is the last frontier in the expansion of area under cocoa, and virgin forests are dwindling fast, the future of Ghana's cocoa appears to hinge on resuscitating production in the cocoa regions besides the Western, and in increasing substantially productivity on existing farms. In this regard, enhancement of the soil fertility status of cocoa farms is critical (Appaih et al. 1997).

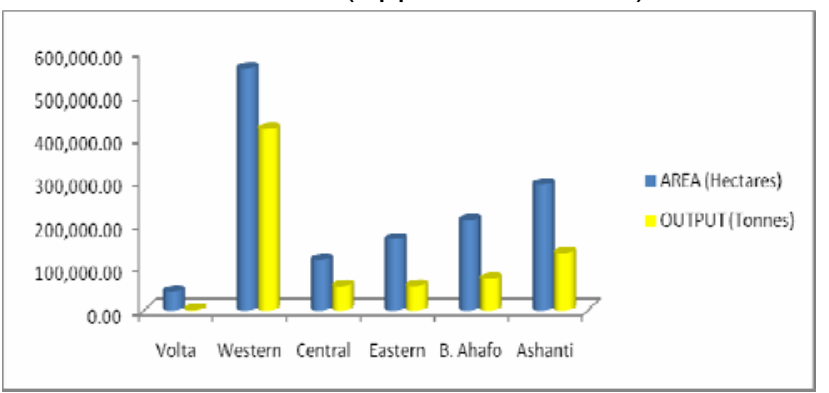

Fig 1: Land area and cocoa outputs in Ghana (2006) Source: Ghana Cocoa Board, CSSVD-CU Cartography Department. 
Results of experimental trials on farmers' farms by Cocoa Research Institute of Ghana (CRIG) indicated that low soil fertility is a major cause of the decline in yields of cocoa farms in Ghana. However, fertilizer application increased yields from $250 \mathrm{~kg}$ per hectare to $1,500 \mathrm{~kg}$ per hectare after the $4^{\text {th }}$ year of fertilizer application (Ghana Cocoa Board, 2002).

To support the quest to empower farmers to adopt improved cocoa production practices and proper farm management to increase productivity, an association known as the Cocoa Abrabopa Association (CAA) came into existence in 1999 with the aim of training and educating cocoa farmers on farm maintenance practices, business and entrepreneurial skills and soil fertility management. This association started with the testing of a package of inputs and farm management practices developed and recommended by the Cocoa Research Institute of Ghana (CRIG). In line with the aspirations of the Cocoa Abrabopa Association (CAA), the main objectives of this study were to access cocoa farmers' production and fertilizer application practices and its effect on soil fertility. The specific objectives were:

i. To assess the relative importance of cocoa to other crops in the study area.

ii. To assess farmers' awareness or knowledge of soil fertility management practices,

iii. To assess the relationship between production practices and yield as a proxy for soil fertility.

iv. To analyze the determinants of fertilizer use by farmers.

\section{METHODOLOGY}

Brief description of study area:

The Eastern Region, with an area of 19,323 square kilometres, occupies 8.1 per cent of the total land area of Ghana, and is the sixth largest region of Ghana (Figure 3). It has a population of 2,106,696 representing 11.1 per cent of Ghana's population. It is the third most populous region, after the Ashanti and Greater Accra. The population is made up of 49.2 per cent males and 50.8 per cent females. The Eastern region is one of the six cocoa producing regions of Ghana, and the first point of cocoa introduction in 1879 (Okali, 1983). Besides cocoa, oil palm, coffee, yams, maize, cassava, livestock and fisheries are important agricultural enterprises. The inhabitants are mainly farmers, fishermen and traders, the proximity to Accra, the national capital enhancing trade links. The trend in cocoa production in the Eastern region from 1995 and 2006 is presented in figure 2. There was a slight increase in production from 2002 to 2004 but declined again from 2004 to 2006.

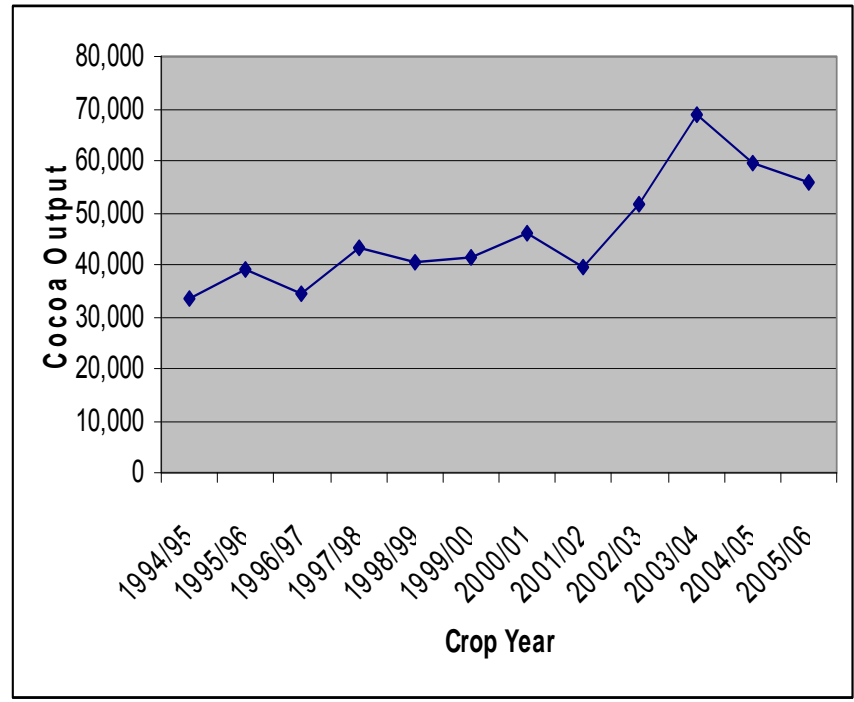

Fig 2: Cocoa output (in MT) in the Eastern region, Ghana (1995-2006)

Source: Ghana Cocoa Board, Accra.

The methodology of this study is survey research which according to De Vaus (2002) is not just a particular technique of collecting information. Questionnaires are widely used but other techniques such as in-depth interviews, observation and content analysis can be used. The methods employed in this study are questionnaire survey and statistical analysis using the Statistical Products and Service Solutions (SPSS) version 16.

Three cocoa districts, Anyinam, Akoase and Akim Oda were randomly selected from a list of districts where the CAA operates. In each district, five cocoa farming communities where CAA and non-CAA members resided were randomly selected with ten farmers being selected from each community to provide a total of 150 farmers. For CAA members, the list of participating members was used as a frame to systematically select the farmers. Non-CAA farmers were selected using farmer lists obtained from the community offices of the Produce Buying Company (PBC), the largest cocoa buying company with purchasing centres in all the communities. Systematic sampling was used to select the non-CAA farmers. The inclusion of CAA members was to test the hypothesis that they were more likely to use fertilizers and other soil fertility management practices than non-CAA farmers. The farmers were interviewed at their convenience on one-on-one basis using standardised questionnaires in January 2009. 
Agric. Biol. J. N. Am., 2011, 2(1): 173-181

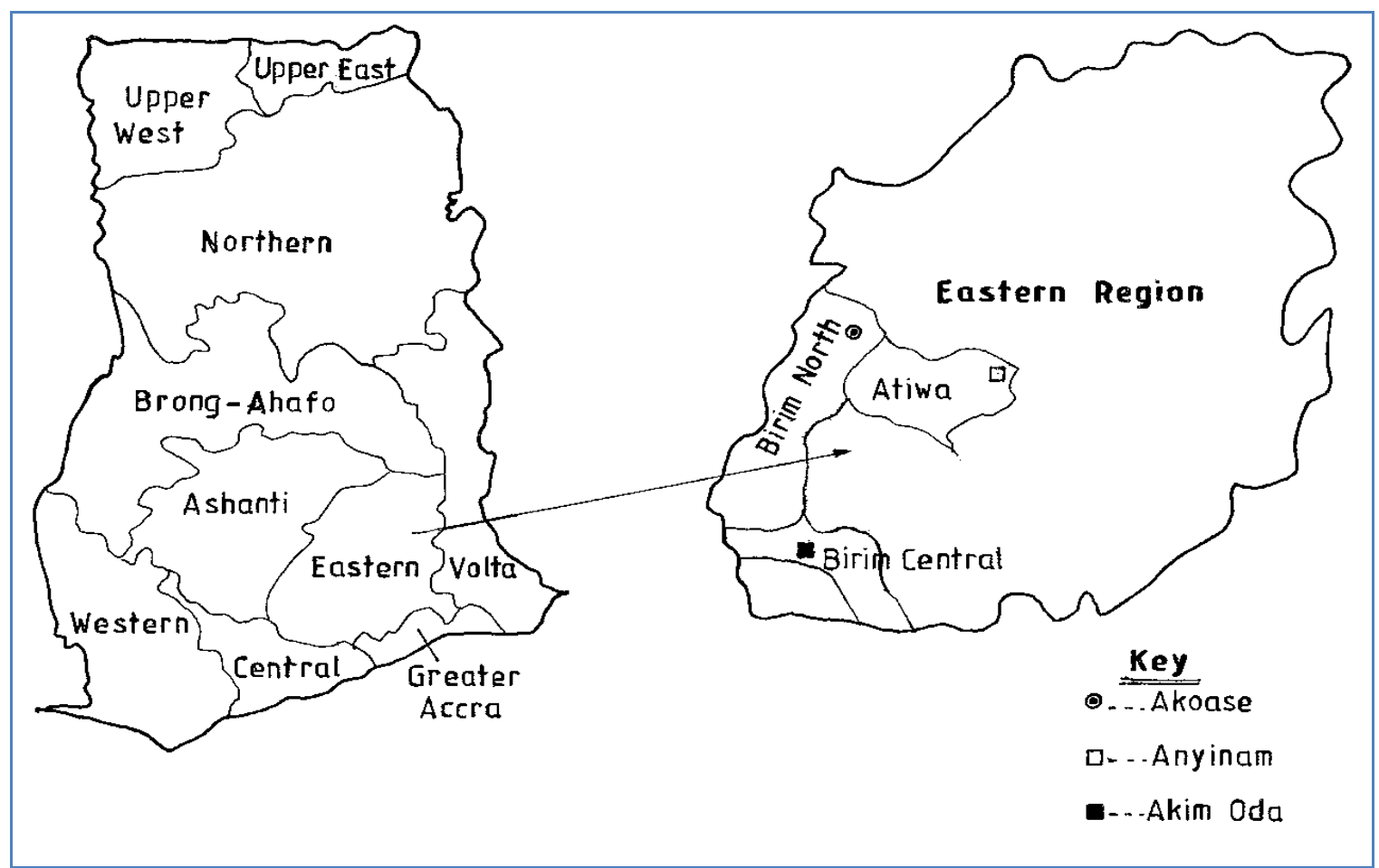

Fig 3. The map of Ghana showing the Eastern Region with Akoase, Anyinam and Akim-Oda Cocoa districts

Descriptive statistics such as frequencies were used to explore the relative importance of cocoa to other crops. Chi square was used to evaluate farmers' awareness and knowledge of soil fertility management practices among CAA and non-CAA farmers.

The Cocoa Research Institute of Ghana (CRIG, 1987) recommends that to optimize output, farmers should apply fertilizers in combination with medium shade, judicious pruning, regular weeding and insecticide spraying. If this recommendation is practiced it is possible for a farmer to realize yields of over 2.0 tons per hectare, with the fertilizer contributing as much as $20-40 \%$ of the increase in yield (Adomako et al, 1995). Based on this recommendation, equation 1 was fitted to the data to evaluate the main factors that contribute to yield on farmers' farms.

$$
\mathrm{i}=6
$$

Equation 1: Yield $=\alpha+\sum_{i=1} \beta i x i+e$

Where $\mathrm{x}_{1}=$ overhead density

$\mathrm{x}_{2}=$ weeding method

$x_{3}=$ number of times of weeding/year

$\mathrm{x}_{4}=$ number of times of applying insecticides $x_{5}=$ number of times of applying fungicides

$x_{6}=$ number of bags of fertilizer applied

$\beta=$ the coefficient of the ith predictor/explanatory variable

$\alpha=$ constant term.

' $e$ ' is assumed to be normally distributed, with a constant variance. Analysis of variance was used to estimate the significance of shade management and month of fertilizer application on yield of Abrabopa and non-Abrabopa farmers and a t-test also used to compare the yield of Abrabopa and non-Abrabopa farmers. Logistic regression analysis was used to analyze the determinants of fertilizer usage by farmers. This is based on the hypothesis:

$Y=f\left(X_{1}, X_{2}, X_{3}, X_{4}, X_{5}, X_{6}, X_{7}, X_{8}, X_{9}, X_{10}\right)$

Where, $Y$ represents farmers' fertilizer adoption in 2008 (Yes or No).

Dichotomous variables were coded 1 and 0 , for instance, yes and no for fertilizer usage and Abrabopa membership; native and settler for the migration status; owner and sharecropper for farmer category; and male and female for sex. For continuous variables, higher values indicated more of the characteristic of interest. ' 1 ' in fertilizer usage corresponding with ' 1 ' in the logistic dichotomous 
dependent variables gives a positive relationship and vice-versa.

The independent variables and the assumptions underpinning the predicted direction with the dependent variable are:

$\mathrm{X}_{1}$ : Age of farmer. It was assumed that as a farmer ages he or she would no longer be interested in exploring certain innovations like fertilizer application hence would not adopt or use the technology at all. A negative relationship between age and adoption or use of fertilizer was predicted.

$\mathrm{X}_{2}$ : Abrabopa membership. It was assumed that since Abrabopa members are provided fertilizer packages on credit, they were likely to use fertilizer relative to other farmers hence a positive relationship was predicted.

$\mathrm{X}_{3}$ : Household size. As the farmers household size increases dependency burden of the farmer also increases, hence the farmer may not be able to invest in his or her farm by using the technology. A negative relationship was predicted.

$\mathrm{X}_{4}$ : Farm size. As the farmer increases the farm size, management becomes difficult leading to poor yield which will encourage the need for fertilizer application on farm. A positive relationship was predicted.

$\mathrm{X}_{5}$ : Yield. Higher yield will enable the farmer obtain more income thus being able to afford fertilizer. A positive relationship was predicted.

$\mathrm{X}_{6}$ : Farmer category. Sharecroppers or caretakers are less likely to use fertilizer since the farms are not their own and were likely to use the fertilizer for crops of their interest which they will solely benefit. Farm owners were more likely to use fertilizers since the benefits accrue to them fully. A positive relationship was predicted.

$\mathrm{X}_{7}$ : Migration status: Settlers are more likely to use fertilizer than natives because of their adventurous nature which will spur them to explore the effects of the technology. A negative relationship was predicted.

$\mathrm{X}_{8}$ : Number of cocoa farms: As the farmer increases the number of cocoa farms, management becomes difficult leading to poor yield which will encourage the need for fertilizer application on farm. A positive relationship was predicted.

$\mathrm{X}_{9}$ : Age of cocoa farm: As the cocoa farm ages, output begins to decline and most farmers were likely to apply fertilizer to raise output. A positive relationship was therefore predicted.

$\mathrm{X}_{10}$ : Sex of respondent: Males were more likely to use fertilizer than females because as heads of most cocoa households, they tend to control the resources of the household including farm purchases. It was also assumed that females were more risk averse than males. A positive relationship was predicted for males and vice versa.

\section{RESULTS AND DISCUSSION}

The general characteristics of the sample are presented in Table 1.

Table 1: General features of respondents

\begin{tabular}{|c|c|c|}
\hline Features & Categories & Percentage \\
\hline \multirow[t]{4}{*}{ Age (years) } & $<18$ & - \\
\hline & $18-39$ & 19 \\
\hline & $40-59$ & 56 \\
\hline & 60 and above & 25 \\
\hline \multirow[t]{2}{*}{ Sex } & Male & 78 \\
\hline & Female & 22 \\
\hline \multirow[t]{2}{*}{ Migration status } & Native & 36 \\
\hline & Settler & 64 \\
\hline \multirow{5}{*}{ Marital status } & Married & 82 \\
\hline & Single & 2 \\
\hline & Widowed & 11 \\
\hline & Divorced & 4 \\
\hline & Consensual union & 1 \\
\hline $\begin{array}{l}\text { Membership of } \\
\text { CAA }\end{array}$ & $\begin{array}{c}\text { Male } \\
\text { Female }\end{array}$ & $\begin{array}{l}81 \\
19\end{array}$ \\
\hline Migration status & $\begin{array}{l}\text { Natives } \\
\text { Settlers }\end{array}$ & $\begin{array}{l}36 \\
64\end{array}$ \\
\hline $\begin{array}{ll}\text { Land } & \text { tenure } \\
\text { status } & \end{array}$ & $\begin{array}{c}\text { Owners } \\
\text { Sharecroppers } \\
\text { Renters/lessees }\end{array}$ & $\begin{array}{c}70 \\
23 \\
7\end{array}$ \\
\hline $\begin{array}{l}\text { Educational } \\
\text { status }\end{array}$ & $\begin{array}{c}\text { Primary } \\
\text { Junior /Middle School } \\
\text { Secondary school } \\
\text { Technical/vocational } \\
\text { school } \\
\text { University/Polytechnic } \\
\text { No farmal education }\end{array}$ & $\begin{array}{c}18 \\
58 \\
4 \\
3 \\
1 \\
16\end{array}$ \\
\hline
\end{tabular}

Source: Survey data

Over 80 percent of the sample has some form of education which is refreshing given the general perception (MASDAR International Consultants, 1998; Ghana Cocoa Board, 1998; Baah, 2006) that the cocoa farming population in Ghana is largely illiterate. With regards to land tenure status, $70 \%$ were owner-operators with relatively fewer proportions of sharecroppers perhaps because the Eastern region does not have much uncultivated land for sharecroppers to access compared to the Western region for instance, which has relatively more sharecroppers of all the cocoa regions (Baah, 2006; Arhin, 1985).

Cocoa is critical to the livelihoods of most farmers sampled in the study. The mean size of cocoa farms 
was 3.67 acres with farmers managing between 1 and 8 farms (Table 2).

It was discovered that farmers have put nearly all their land under cocoa in the hope that it will provide them security of income over many years. Besides cocoa, the food crops are critical to farmers' survival. All farmers have small patches of food crops such as plantain, cocoyam, cassava and maize either within the cocoa or in close proximity.

Awareness and knowledge of soil fertility management: Access to information about a piece of agricultural technology may not be a sufficient condition to induce adoption by farmers, but it is a critical first step in the technology evaluation process (Van den Ban, 1998; Rogers, 1995). The expectation was that farmers who were members of the Cocoa Abrabopa Association (CAA), an association which focuses on training of farmers in soil fertility management practices including fertilizer application will have significantly higher awareness of soil fertility and management issues than non-CAA farmers. The study found that only $52 \%$ of respondents had knowledge of indicators that would enable them to detect declining fertility status of their cocoa farm. Of this proportion, and as anticipated, most of them $(96 \%)$ are CAA members with the differences between them and non-CAA farmers being significant $(P<0.05)\left(X^{2}=8.632, p=0.003\right)$. In addition to declining yield, other indicators of declining soil fertility status of the soil include changes in soil and leaf colours (Table 3).

Other practices that farmers mentioned they use to manage the fertility status of the soil include the addition of crop residues $(26 \%)$ and control of soil run-off $(46 \%)$. The differences between CAA and non-CAA farmers on these practices were not significant $\left(x^{2}=3.678, P=0.342\right)$.

Fertilizer use by farmers: The recommendation of the Cocoa Research Institute of Ghana (CRIG, 1987) is that fertilizers should be applied once a year at the beginning of the rains (April-May). Both Abrabopa members and non-Abrabopa members who used fertilizer in 2007 adhered to this recommendation. However, non-CAA farmers and 32 percent of CAA farmers applied fertilizers in 2007/8 cocoa season at the wrong time because of delays in fertilizer delivery to their communities. Other details on fertilizer application by farmers in the three districts are presented in Table 4.

Pests and diseases control: The benefits of fertilizer and other soil ameliorates applied to cocoa farms may be lost if pests (mainly mirids) and diseases (mainly blackpod caused by phytophthora species) are not managed (CRIG, 1987). Indeed, Asante (1992) and Adomako et al, (1995) showed that without the control of these pests and diseases it is unprofitable to apply fertilizer. Sixty-five percent of all respondents reported using fungicides and cultural practices such as shade manipulation to control blackpod disease, whilst 96 percent of CAA members an 50 percent of non-CAA farmers controlled mirids through spraying the cocoa with Confidor insecticide. The higher proportion of CAA farmers engaged in pests and diseases control could be attributed to the intensive education to which they are subjected compared to non-CAA farmers.

Production practices and cocoa yield : Regression analysis conducted on the model: Yield $=\mathrm{f}$ (overhead density, weeding method, number of times of weeding/year, number times of applying insecticides, number of times of applying fungicides, number of bags of fertilizer applied) showed that the combined effect of the production practices listed made no significant contributions to the yield. Only $5.8 \%$ of the variation in the yield could be explained by the predictors (Table 5). This contradicts expectations based on CRIG (1987) recommendations to the effect that fertilizer application in combination with medium shade, judicious pruning, regular weeding and insecticide spraying, the combined effect could results to yields of over 3.0 tons per hectare, with fertilizer alone contributing $20-40 \%$ of the yield.

Table 2: Number of Farms Managed By cocoa farmers in the Eastern Region, Ghana

\begin{tabular}{|l|l|l|l|l|l|l|}
\hline Feature & $\mathrm{N}$ & Min. & Max. & Mean & Std. & Skew. \\
\hline Number of cocoa farms managed in 2006 & 150 & 1.00 & 8.00 & 3.066 & 1.288 & .733 \\
\hline Number of cocoa farms managed in 2007 & 150 & 1.00 & 6.00 & 2.106 & 1.043 & 1.040 \\
\hline
\end{tabular}


Agric. Biol. J. N. Am., 2011, 2(1): 173-181

Table 3: Some Indicators of declining soil fertility of cocoa soils mentioned by farmers in Eastern Region, Ghana

\begin{tabular}{|l|c|c|c|}
\hline Indicators & Abrabopa Farmers & Non-Abrabopa Farmers & Total \\
\hline Soil colour & $9(12.0)$ & $0(.0 \%)$ & $9(11.5)$ \\
\hline Declining yield & $41(54.7)$ & $3(100.0)$ & $44(56.4)$ \\
\hline Yellowing of crop leaves & $9(12.0)$ & $0(.0)$ & $9(11.5)$ \\
\hline Others & $14(18.7)$ & $0(.0)$ & $14(17.9)$ \\
\hline Total & $75(100.0)$ & $3(100.0)$ & $78(100.0)$ \\
\hline
\end{tabular}

Source: Survey data. Figures in parentheses are percentages

Table 4: Information on Fertilizer Usage by Farmers in the Eastern Region, Ghana

\begin{tabular}{|c|c|c|c|c|}
\hline \multirow{2}{*}{$\begin{array}{l}\text { PRACTICES } \\
\text { Month of Fertilizer Application }\end{array}$} & \multicolumn{2}{|c|}{ Abrabopa Farmers } & \multicolumn{2}{|c|}{ Non-Abrabopa Farmers } \\
\hline & Frequency & Percentage & Frequency & Percentage \\
\hline February & 1 & 1 & - & - \\
\hline March & 4 & 5 & 2 & 67 \\
\hline April & 12 & 16 & - & - \\
\hline May & 37 & 49 & - & - \\
\hline June & 11 & 15 & - & - \\
\hline July & 2 & 3 & 1 & 33 \\
\hline April-May & 2 & 3 & - & - \\
\hline May-June & 1 & 1 & - & - \\
\hline June-July & 1 & 1 & - & _- \\
\hline August & 3 & 4 & - & - \\
\hline September & 1 & 1 & - & - \\
\hline \multicolumn{5}{|l|}{ Method of Application } \\
\hline Broadcast & 74 & 99 & 1 & 33 \\
\hline Ring application & 1 & 1 & 2 & 67 \\
\hline \multicolumn{5}{|c|}{ Number of times fertilizer was applied } \\
\hline Once & 75 & 100 & 3 & 100 \\
\hline \multicolumn{5}{|l|}{ Twice } \\
\hline \multicolumn{5}{|l|}{ Type of fertilizer } \\
\hline Asasewura & 75 & 100 & 3 & 100 \\
\hline
\end{tabular}

Source: Survey data

Table 5: Factors influencing farmers' cocoa yield in the Eastern Region of Ghana

\begin{tabular}{|l|r|}
\hline & \multicolumn{1}{|c|}{ Standardized Coefficients } \\
\hline Model & Beta \\
\hline (Constant) & .548 \\
\hline Density of overhead shade & .502 \\
\hline Weeding method used & .079 \\
\hline Number of weeding & .130 \\
\hline Number of times field sprayed against capsids & .097 \\
\hline Number of times field sprayed against blackpod & .412 \\
\hline Number of bags of fertilizer applied per acre & .030 \\
\hline Dependent Vabie & .294 \\
\hline
\end{tabular}

Dependent Variable: Yield of Cocoa Harvested in 2007

$F_{(6,71)}=0.725, p=0.631, R^{2}=0.058$ 
Farmers in this study weeded their farms an average of three times in a year, sprayed their farms against blackpod and mirids four and three times per year respectively. Forty-one percent $(41 \%)$ of the farmers had low shade density on their farms, 32\% medium shade density and $27 \%$ high shade density on their farms. The average yield of cocoa farms in the study was $432 \mathrm{~kg}$ per hectare. Though farmers applied fertilizers at the recommended periods many failed to control pests and diseases effectively. In addition, the level of shade on most farms was not optimal leading to the masking of the potential effect of the fertilizer on yield. This proposition is confirmed by the results of the regression analysis (Table 5 ) and the findings of Adomako et al (1995) and Opoku-Ameyaw et al (1999). The data from this study suggests that ineffective husbandry practices including pests and diseases control and optimal shade among others tend to reduce the impact of fertilizer application on cocoa yield.

Comparing CAA and non-CAA Farmers: Using a two-way between-groups analysis (factorial ANOVA) with equal variance assumed to explore the impact of Abrabopa membership and month of fertilizer application on cocoa yields of respondents, it was observed that there was no statistically significant interaction effect $\left(F_{(2,134)}=1.049, p=0.353\right)$ on the yields of the farmers. There was also no statistically significant main effect of Abrabopa membership ( $F_{(1}$, 134) $=0.939, p=0.334$ ) as well as the months of fertilizer application $\left(F_{(1,134)}=1.677, p=0.085\right)$ on the yields of farmers. The result implied that whether a farmer belonged to Abrabopa association or not and which month fertilizer was applied to farm did not have any significant effect on yield. This could be explained by the revelation earlier that $32 \%$ of Abrabopa farmers and the entire non-Abrabopa farmers who used fertilizer applied them at wrong periods (Table 4 ).

Further comparison of the combined effect of Abrabopa membership and shade management on yield gave a statistically significant main effect of Abrabopa membership on the farmers' yield $\left(F_{(1,138)}\right.$ $=11.492 \mathrm{p}=0.001)$, but the interaction effect $\left(F_{(2,}\right.$ $\left.{ }_{138)}=0.756, p=0.556\right)$ and the main effect of shade management $\left(F_{(1,138)}=2.453, p=0.037\right)$ were not significant. The statistically significant main effect of Abrabopa membership on the farmers' yield obtained using the two-way ANOVA was confirmed in an independent-sample T-test conducted to compare the mean yields for the two groups which showed very significant differences $(t=5.303, d f=121, p=0.000)$. The magnitude of the difference in the mean yields of both groups was very large (eta square calculated = 0.16). This implies Abrabopa members had higher output $(562.5 \mathrm{~kg} / \mathrm{ha})$ from their cocoa farms than the non-Abrabopa members (237 kg/ha). This could be attributed to the differences in the number of bags of fertilizers applied. The independent-sample t-test conducted showed that Abrabopa members applied an average of 3 bags of fertilizer per acre while nonAbrabopa members applied an average of only 1 bag of fertilizer per acre of cocoa farm, the difference being highly significant $(t=5.75, p=0.000)$.

Determinants of fertilizer use by farmers: Using logistic regression analysis with SPSS, it was observed that the model as stated in the method of analysis had a good fit (omnibus tests of model coefficients was significant with $x^{2}=148.312, p=$ 0.000 ) and the Hosmer and Lemeshow test for poor fit was not significant (with $x^{2}=4.440, p=0.815$ ). The variation in the data explained by the model according to the Cox and Snell $\mathrm{R}^{2}$ was $65.1 \%$ and $86.9 \%$ according to the Negerkeke $R^{2}$. That is, the logistic independent variables stated could explain $65.1 \%$ to $86.9 \%$ of the variability in the adoption or use of fertilizer by farmers.

Meanwhile the significant predictors of the model were Abrabopa membership (ABRABMEM), the size of the farms (SIZEF), the yield of cocoa harvested (BCOCO1PA), the migration status of the farmer (MIGSTAT) and the number of cocoa farms a farmer has (NCOCOF) (Table 6). This suggests that the probability of a farmer using fertilizer depended on these predictors. The insignificant predictors were the age of the farmer (HOLD), the household size of the farmer (NPEPOT), the farmer category (FARMCAT), the age of cocoa plantation (AGEPLT) and sex of the farmer (SEX). Testing the hypothesis set with the significant predictors in terms of the direction, it was realized that:

- Abrabopa members were more likely to use fertilizer having a positive $B$ value and a very large Exponential $B$ value. Hence the positive relationship predicted was attained (hypothesis validated).

- Also as the size of a farmer's farm increases, he/she is more likely to use fertilizer. Hence a positive relationship predicted was confirmed (hypothesis validated). 
- As the farmer harvest more cocoa, he or she is more likely to use fertilizer, also confirming the positive relation predicted (hypothesis validated).

- Natives were also more likely to adapt to fertilizer usage than the settlers. This is a deviation from the hypothesis stated (hypothesis invalid).
- As the number of cocoa farms of a farmer increases, the farmer is more likely use fertilizers to optimize output (positive relationship predicted was confirmed).

Table 6: logistic regression on fertilizer use by farmers in the Eastern Region of Ghana

\begin{tabular}{|l|c|c|c|}
\hline Variables & Beta & Significance & Exp(B) \\
\hline HOLD & .774 & .122 & 2.167 \\
\hline ABRABMEM(1) & 7.168 & .000 & 1297.454 \\
\hline NPEPOT & -.231 & .524 & .793 \\
\hline SIZEF1 & .164 & .016 & 1.178 \\
\hline BCOCO1PA & .747 & .008 & 1.111 \\
\hline FARMCAT(1) & .418 & .633 & 19.599 \\
\hline MIGSTAT(1) & 2.975 & .026 & .421 \\
\hline NCOCOF & -.865 & .019 & 1.035 \\
\hline AGEPLT1 & .035 & .309 & 6.481 \\
\hline SEX1(1) & 1.869 & .120 & .000 \\
\hline Constant & -10.464 & .001 & \\
\hline
\end{tabular}

The significant effect of migration status on fertilizer use could be attributed to the fact that natives tend to exploit their kinship ties to acquire land relatively easily compared to settlers. This assertion is supported by the work of Okali (1983) and Hill (1963) that examined the exploitation of kinship ties and networks in the expansion of cocoa in southern Ghana and concluded that these ties were critical in making many landless individuals and groups' landowners. In this regard, natives could easily increase their farm sizes or own more cocoa farms. As they increase their farm sizes and numbers, managing the farms then become difficult, hence causing them to experience low yields. This is likely to urge them to adopt fertilizer usage to enable them increase their cocoa yields. As yield increases, farmers would then have more income to patronize more fertilizer. The significance of a farmer being a member of Abrabopa association in relation to fertilizer use is related to the fact that Abrabopa members are more likely to use fertilizer since this is part of the package given to members of the association. Membership of CAA is not influenced by a farmer's migration status as the Chi-square test examining the relationship between CAA membership and migration status was not significant $(x 2=0.186, p=0.666)$.

\section{CONCLUSIONS AND RECOMMENDATIONS:}

Productivity on cocoa farms in the Eastern Region are low but could be raised through a combination of enhanced husbandry practices such as effective weed, pests and diseases control, pruning and shade management. The findings of this study suggest that the positive effects of these practices on cocoa yield could be further enhanced by farmers maintaining the fertility status of their soils. Whilst farmers do undertake soil fertility management practices such as application of crop residue and control of run-off water, the dominant practice which has significant impact on cocoa yield is application of fertilizers. The significantly higher yield obtained by the CAA farmers suggest that the CAA package of husbandry practices backed by effective extension support which provides farmers with the information they need about fertilizer use is an effective one which could lead farmers away from low yields and incomes to increased productivity, incomes and secured livelihood.

Even for CAA farmers, the yield of dry cocoa beans obtained is still low relative to the potential yield of over 2.5 tonnes per hectare. Besides effective husbandry practices and fertilizer application, farmers need all the technical and business skills to approach cocoa farming as a business enterprise. To achieve 
this, an effective farm management extension system should be in place to support farmers. CAA has shown the way in terms of extension provision but this is limited in scale and governmental support is needed. The current state of public sector cocoa extension leaves much to be desired and the extensive use of farmers' associations as platform for interactive communication between farmers, extension agents and other stakeholders in the cocoa sector is desired.

\section{ACKNOWLEDGEMENTS}

The technical assistance of Edwin Badger, Dickson Adjepong and Alberta Badu-Yeboah are acknowledged. This paper is published by the kind permission of the Executive Director of Cocoa Research Institute of Ghana (CRIG).

\section{REFERNCES}

Adomako, D., Halm, B. J. and Amponsah, J.D. (1995) Summary of Innovations/Recommended Technologies for Cocoa, Coffee, Sheanut and Kola Production and Current Research Activities. Tafo: Cocoa Research Institute of Ghana.

Ahenkora, Y. (1997). Management of Soil Fertility for Sustainable Agriculture in the Humid and Sub-Humid Tropics of Africa. Proc. Soil Sci. Soc. Ghana Vol. 14 and 15. Kumasi, Ghana.

Appiah, M., R., (2004). Impact of Cocoa Research innovation on Poverty Alleviation in Ghana. Inaugural lecture, Ghana Academy of Arts and Sciences, Ghana.

Appiah, M. R., Ofori-Frimpong, K., Afrifa, A.A. and Asante, E.G. (1997). Prospects of Fertilizer Use in the Cocoa Industry in Ghana. Proc. Soil Sci. Soc. Ghana Vol. 14 and 15. Kumasi, Ghana.

Arhin, K. (1985). The Expansion of Cocoa Production in Ghana: The Working Conditions of Migrant Cocoa Farmers in the Central and Western Regions. Legon: Institute of Statistical, Social and Economic Research, University of Ghana.

Asante E. G. (1992). Benefit-Cost Analysis of CRIGRecommended Technologies in Relation to Farmer Adoption Patterns and Implication for the Cocoa Industry in Ghana. Management Thrust discussion paper, Nov. 1992. Tafo: CRIG.

Baah, F. (2008). Harnessing Farmer Associations as Channels for Enhanced Management of Cocoa Holdings in Ghana. Scientific Research and Essays, vol.3 (9) pp. 195-200.
Baah, F. (2006). Cocoa Cultivation in Ghana: An Analysis of Farmers' Information and Knowledge Systems and Attitudes. PhD thesis, Institute of International Development and Applied Economics, University of Reading, UK.

Baah, F. (2002). Towards a Pluralistic Approach in Extension Services Delivery to Ghanaian Cocoa Farmers. Journal of the Ghana Science Association, Vol. 4 (1): 78-82.

Cocoa Research Institute of Ghana (CRIG) (1987). A Guide to Cocoa Cultivation. Tafo: Cocoa Research Institute of Ghana.

De Vaus, D. (2002). Surveys in Social research $\left(5^{\text {th }}\right.$ edition). London: Rutledge.

Ghana Cocoa Board (2002). Report of the Committee on Application of 'High Technology' Method on Cocoa Production in Ghana. Accra: Ghana Cocoa Board.

Ghana Cocoa Board (1998). Report on the Causes of recent Decline in Cocoa Output and Measures to Revamp the Sector. Accra: Ghana Cocoa Board.

Hill, P. (1963). The Migrant Cocoa Farmers of Southern Ghana: A Study in Rural Capitalism. Cambridge: Cambridge University Press.

International Cocoa Organization (ICCO) (2007). Annual Report 2005/2006. London: ICCO

ISSER, (2008). The State of the Ghanaian Economy in 2007. Institute of Statistical, Social and Economic Research, University of Ghana. Legon.

MASDAR International Consultants (1998). SocioEconomic Study of cocoa farming in Ghana. Consultancy Report, Accra: Ghana Cocoa Board/MARSDAR International Consultants.

Okali, C. (1983). Cocoa and Kinship in Ghana: The Matrilineal Akan of Ghana. London and Boston: Kegan Paul International.

Opoku-Ameyaw, K., Appiah, M. R., Ofori-Frimpong, K. and Afrifa, A.A. (1999). The Response Cocoa Yield To Fertilizer Application under Different Farm Maintenance Practices. Proc. Soil Sci. Soc. Ghana Vol. 16. Kumasi, Ghana.

Rogers, E.M. (1995). Diffusion of Innovations. New York: Free Press, fourth edition.

Van den Ban, A.W. (1998). Supporting Farmers' Decision Making Processes by Agricultural Extension. Journal of Extension Systems, Vol. 14 (1): 55-67. 